\title{
Cerebral gigantism-jaw cysts syndrome
}

INSERM

\section{Source}

INSERM. (1999). Orphanet: an online rare disease and orphan drug data base. Cerebral gigantism-jaw cysts syndrome. ORPHA:2081

Cerebral gigantism-jaw cysts syndrome is characterised by cerebral gigantism associated with a jaw cyst basal cell naevoid syndrome. 